\title{
Creative Personality Factors and Practices Among Mathematics Teachers: Principal Component Analysis Approach (PCA)
}

\author{
Nazeri Mohammad PhD. \\ Shuhari Abd. Razak PhD. \\ Research and Innovation Department, \\ Institute of Teacher Education Perlis Campus, \\ Behor Pulai Road, 01000 Kangar, Perlis. MALAYSIA \\ drnazeri.ipgm@gmail.com
}

\author{
Rosnizam Kamis \\ Muhammad Adli Haron \\ Tuanku Syed Sirajuddin Polytechnic, \\ 02600 Arau, Perlis. MALAYSIA \\ Tee_buu@yahoo.com.my \\ mami1702@yahoo.com
}

\begin{abstract}
The practice of effective teaching is associated with the creative nature which is not just teachers plan learning activities, but also includes elements of creativity in the teaching process in the classroom. This study aims to make testing for the instrument creative teaching practices among Mathematics teachers in secondary schools in the northern and central regions of Peninsular Malaysia using sectional survey using a questionnaire creative teaching practices from the perspective of the teacher. A total of 260 mathematics teachers selected by cluster sampling various levels. The principal component analysis (principal component analysis, PCA) was used by SPSS version 20. Results of the analysis showed that the data does not have a serious problem of multicollinearity; it allows the items may be carried out next factor analysis. Therefore Instruments Personality Factor Questionnaire and Creative Teaching Element developed is suitable for studying the creative teaching practices among secondary school teachers of mathematics in Peninsular Malaysia.
\end{abstract}

Keywords-Creative teaching practices; creative personality factors; Mathematics; analysis principal components; factor analysis.

\section{INTRODUCTION}

Creative Personality is an attempt to enact creativity in personalized aspect. Subordinate factors of creative personality is enacted various point of view [8]. The purpose of this study is to make testing for the instrument creative teaching practices among Mathematics teachers in secondary schools in the northern and central regions of Peninsular Malaysia using sectional survey. Creative personality is an intersection between creative and personality [13].

Recently creative and creativity in education is a global trend. But personality is as important as that. Many research about creativity in education have been done, but research about personality aspect of creative personality factors are not enough. Personality is an individual difference that should not be overlooked [9]. Several studies have been conducted in an attempt to link personality with elements of creativity in the teaching process in the classroom [8][12].
Adopting quality classroom teaching strategies for effective instruction had generated serious debate and ideological controversy among classroom teachers, teacher educators and researchers in mathematics education[14]. Most classroom activities are teacher-centred with students as mere listeners and recipients of knowledge rather than being active initiators of their knowledge [13]. Therefore, it is important that the pedagogical strategies we employ in the classroom during mathematics classroom instruction should reflect an understanding of the different students' identities that exist in the mathematics classroom so that we can anticipate the tensions that might occur in the classroom and be proactive about them [14]. The mathematics teacher most also work hard by enhancing students' ability to participate in a pluralistic, and interdependent classroom activities which in turn will increase the level of students engagement and participation in mathematics classroom activities [12][13].

The teachers are very important in determining the choice of teaching practice [8]. The role of the teacher studentcentered teaching practice change the form of teaching that focus on student thinking to be more open and able to build their own knowledge [8][9].

Teachers are more creative in teaching by gathering students based on ability and mastery of a skill [9][13]. Creative teachers also provide a wide range of challenging situations to be explored by the students and encourage students to think of everything that can be produced from such situations [8][9]. There is sample evidence to show the characteristics of teaching interested students are influenced by factors such as the field they studied [12]. Students tend to learn academically appropriate to their learning approach and personality [9]. Moreover they will adapt to meet specific needs or style of thinking and learning in the academic field or the course. Students also available feature a variety of teaching both academic varying [8][9][12]. 
The tendency towards a particular teaching style and the characteristics of the other teachers found to have links with a variety of features such as the student's cognitive style and personality. Nazeri \& Ruhizan found that students who have a similar view to the effective teaching of its teachers will assume the teacher is effective [8][9].

Attitude towards education also corresponds to the teaching style of great interest to students [9]. Nazeri \& Ruhizan also identify the relationship between students' learning approach with teachers who preferred communication style. Some studies suggest learning approach is related to the characteristics of the teaching and behavior of interest [8][9].

Summary of the results of previous studies prove the importance of creative teaching practices in the education system in line with the Ministry of Education (MOE) to produce students who are creative and competitive in the era of globalization and can enhance human capital excellence [9].

\section{RESEARCH METHOD}

The sample consisted of 260 teachers selected for sampling Mathematics clusters varying degrees at 87 schools in the northern and central region of Peninsular Malaysia based on the recommendations of Hair et al. (2010), five of the respondents attributed to the item. The number of items or variables observed in this study is 51 items. Thus, the number of samples required is $51 \times 5$ respondents per item amounting to a total of 255 respondents. Therefore researchers have taken the appropriate number of samples as recommended, a total of 260 respondents from among secondary school mathematics teacher in a zone that has been explained earlier[5]. This amount is sufficient to meet the needs of the population and factor analysis as recommended[2][5]. In determining the sample of this study, several factors counting samples were also taken into account such as study design and statistical analysis procedures [2][5]. The proposed minimum sample for statistical analysis of procedures related to the study are summarized in Table I

TABLE I. MINIMUM NUMBER OF SAMPLES BASED ON STATISTICAL PROCEDURES

\begin{tabular}{|l|l|}
\hline $\begin{array}{l}\text { Statistical Analysis } \\
\text { Procedure }\end{array}$ & $\begin{array}{l}\text { The minimum number of samples } \\
\text { required }\end{array}$ \\
\hline $\begin{array}{l}\text { Exploration Factor } \\
\text { Analysis (EFA) } \\
\text { Principal component } \\
\text { analysis (PCA) }\end{array}$ & $\begin{array}{l}\text { At least } 100 \text { or at } 5 \text { or } 20 \text { times the } \\
\text { number of variables. }\end{array}$ \\
\hline \multicolumn{2}{|c|}{ Resource: Hair et al. (2010), Ullman (2007, Brown (2006) and Kline (2005) }
\end{tabular}

Factor analysis was conducted to identify factors or components present in a set of instruments or questionnaires that have been built [1][7]. The principal component analysis is statistical factor analysis techniques that alter the original data set linearly to construct a set of smaller constructs to provide a comprehensive overview of all the information available in the original construct [4]. The objective of this type of factor analysis is to reduce the dimensions of the original data to a number of smaller components and can be interpreted more easily and means [2][3].The first stage is to calculate the correlation matrix between all constructs that have analyzed factors[11]. The next stage is the retract extracting some of the correlation matrix of factors and determine how many of the factors that shape. These analysis factors done to improve the interpretation that this was a factor that becomes more meaningful and can be interpreted[10]. The last and important stage in the analysis of these factors is to interpret the results obtained factors and rename to construct a new label for each factor that formed the basis of the literature study and previous studies[2][5][11].

\section{RESULTS AND DISCUSSION}

\section{A. Reliability}

Alpha value must exceed 0.50. Whereas is the minimum value must be greater than or equal to $0.60[1,2,5]$. In this study, Cronbach Alpha value is above 0.70, therefore, it meets reliability. Specifically Alpha values in this study are shown in Table II.

TABLE II. The CRonbach ALPHA Reliability VALUeS For the VARIABLES.

\begin{tabular}{|l|c|c|c|}
\hline \multicolumn{1}{|c|}{ Variables } & $\begin{array}{l}\text { Num. } \\
\text { item }\end{array}$ & $\begin{array}{l}\text { Num. Items } \\
\text { removed }\end{array}$ & $\begin{array}{l}\text { Alpha } \\
\text { Cronbach } \\
\text { Values }\end{array}$ \\
\hline \multicolumn{3}{|c|}{ Creative Personality } \\
\hline Innovative & 4 & - & 0.85 \\
\hline spontaneous & 5 & - & 0.83 \\
\hline Dedication & 5 & - & 0.82 \\
\hline Do not give up & 5 & - & 0.93 \\
\hline easily & 5 & - & 0.88 \\
\hline Joyful & 5 & - & 0.89 \\
\hline Love challenges & 4 & - & 0.86 \\
\hline \multicolumn{3}{|c|}{ Elements of Creative Teaching } \\
\hline $\begin{array}{l}\text { Designing teaching and } \\
\text { learning. }\end{array}$ & 5 & - & 0.78 \\
\hline $\begin{array}{l}\text { Guide and facilitator } \\
\text { Assess. continuously. }\end{array}$ & 4 & - & 0.80 \\
\hline $\begin{array}{l}\text { Manages the learning } \\
\text { environment. }\end{array}$ & 4 & - & 0.76 \\
\hline $\begin{array}{l}\text { Building a learning } \\
\text { community (online) }\end{array}$ & 3 & - & 0.84 \\
\hline
\end{tabular}

\section{B. Factor Analysis}

Factor analysis, conducted using round varimax to confirm 11 constructs, studied the 6 constructs for personality creative (innovative, spontaneous, dedication, not easily satisfied, joyful and adventurous) and 5 construct elements of creative teaching of design teaching, guiding and facilitating, continuously assess, manage environments and develop learning community (online). Results indicate completion of 11 factors with Eigen values greater than 1.0.

KMO tests indicate multi collinearity. If the same correlation exists between two or more items, the items were measuring the same aspects. KMO test could help researchers 
to identify whether the items are suitable or not suitable for factor analysis. Test results Kaiser-Meyer-Olkin (KMO) to 51 items ( 6 construct creative personality factors and 5 construct creative teaching element) has shown the value obtained was $0.93 \mathrm{KMO}>0.6$. This shows that the data does not have a serious problem of multi collinearity, it allows the items may be carried out next factor analysis. Test of Sphericity Barlett's test used to determine whether a correlation between items adequate for factor analysis. Test results of Sphericity Barlett's is significant (Chi square $=9658.3, \mathrm{p}<0.05$ ) showed that the correlation between the items is adequate for factor analysis. The results of the factor analysis of questionnaire containing 51 items with 11 components (factors) give eigenvalues greater than 1 . All of these factors (11 parts) was accounted for 72.35 percent of the total variance. The amounts of variance to the recommendations of Hair et al (2010) suggest that the amount of variance explained must exceed $60 \%$. KMO tests indicate multicollinearity. If the same correlation exists between two or more items, the items were measuring the same aspects. KMO test could help researchers to identify whether the items are suitable or not suitable for factor analysis. Test results Kaiser-Meyer-Olkin (KMO) to 51 items ( 6 construct creative personality factors and 5 construct creative teaching element) has shown the value obtained was $0.93 \mathrm{KMO}>0.6$. This shows that the data does not have a serious problem of multicollinearity; it allows the items may be carried out next factor analysis. Test of Sphericity Barlett's test used to determine whether a correlation between items adequate for factor analysis. Test results of Sphericity Barlett's is significant (Chi square $=9658.3$, $\mathrm{p}<0.05$ ) showed that the correlation between the items is adequate for factor analysis[5]. The results of the factor analysis of questionnaire containing 51 items with 11 components (factors) give eigenvalues greater than 1 . All of these factors (11 parts) were accounted for 72.35 percent of the total variance. The amounts of variance to the recommendations of Hair et al (2010) suggest that the amount of variance explained must exceed $60 \%[5][11]$.

\section{CONCLUSION}

The results show that the classification of Alpha value is very high and higher than 0.80 . This instrument has high reliability [1] [2], while the factor analysis has shown there are 11 factors that shape. Each item in this construct showed a fairly good load factor of more than 0.5 [5]. Therefore Instruments Personality Factor Questionnaire and Creative Teaching Element developed is suitable for studying the creative teaching practices among secondary school teachers of mathematics in Peninsular Malaysia in the context of education in Malaysia. This caused the educators need to constantly improve their potential as a presenter of knowledge to a level that better suit the changing times [8].

Therefore it is proposed to approach the teacher needs to keep pace with globalization and have the skills and knowledge to realize the atmosphere of creativity, space and creative teaching [9]. This also helped to facilitate students' engagement, collaboration and interest in mathematics during the research as the students felt included in the mathematics classroom instruction [13]. Future researches could be addressed to the knowledge of the relation between creative personality factors and dimensions of interpersonal adjustment, considering as mediating creative personality.

\section{References}

[1] Babbie, E. (2013). The practice of social research. California: Wardsworth Publishing Company.

[2] Byrne., Barbara. M. (2010). Modeling With AMOS: Basic concepts, application and programming. Second Edition. Routledge: New York.

[3] Duntemen G.H (1989), Principles components analysis:Quantitative applications in the social sciences. California: Sage Publications, Inc.

[4] Fields A. (2006). Discovering statistics using SPSS. London: Sage Publications, Inc.

[5] Hair, J.F., Black, W. C., Babin, B. J., Anderson, R. E., \& Tatham, R. L. (2010). Multivariate data analysis. New Jersey: Pearson Internationa Edition.

[6] Lewis Beck, M.S. (1994). Factor analysis and related techniques. London: Sage Publications, Inc.

[7] Mohd Najib Abd. Ghafar. (2003). Research Education. Johor: University Teknologi Malaysia Publisher.

[8] Nazeri Mohammad and Ruhizan Mohamad Yasin. (2011). development Model Creative Teaching in the Field of Design and Technology in Schools. Graduate Research Seminar Proceedings of the National University of Malaysia. Jil. 2, No.1 Februari 2011. 50 - 63. ISSN: 2180-1525

[9] Nazeri Mohammad and Ruhizan Mohamad Yasin.(2010). Teaching practice Teachers in Design and Technology: Review of perspective students a variety of elective. International Seminar on Education Diversity Students di Hotel Equatorial, Bangi.

[10] Sekaran, U. (2003). Research methods for business: A Skill Building Approach (2nd Edition). New York: John Wiley \& Sons, Inc

[11] Tabachnick, B.G., \& Fidell, L.S. (2007). Using multivariate statistics (5th ed.).Boston: Pearson Education Inc.

[12] Seong-Sook Kim. (2011). A Study on Fusion-Type TeachingLearning Method for Art and Science.Gyeongin National University of Education Press.

[13] Schleicher, A. (2016), Teaching Excellence through Professional Learning and Policy Reform: Lessons from Around the World, International Summit on the Teaching Profession, OECD Publishing, Paris.

[14] Stigler, J. W., \& Hiebert, J. Improving Mathematics Teaching; Improving Achievement in Math and Science, 2004, 61(5), pp $12-17$ 